\title{
GAMBARAN ASUPAN DAN STATUS GIZI PADA PASIEN RAWAT INAP PENYAKIT TUBERKULOSIS DI RUMAH SAKIT UMUM DAERAH LABUANG BAJI MAKASSAR TAHUN 2018
}

\section{DESCRIPTION OF INTAKE AND NUTRITIONAL STATUS OF PATIENTS HOSPITALIZED FOR TUBERCULOSIS DISEASE IN LABUANG REGIONAL GENERAL HOSPITAL OF MAKASSAR IN 2018}

\author{
Nalurinita Diniari ${ }^{1}$, Devintha Virani ${ }^{1}$, Citrakesumasari $^{1}$ \\ (Email/Hp: nalurinita@gmail.com/082247937228)
}

${ }^{1}$ Program Studi Ilmu Gizi, Fakultas Kesehatan Masyarakat, Univesitas Hasanuddin, Makassar

\begin{abstract}
ABSTRAK
Pendahuluan: Tuberkulosis merupakan penyakit infeksi akibat kuman Mycobacterium yang bersifat sistematis (menyeluruh). Kuman Mycobacterium ini berbentuk batang, mempunyai sifat khusus yaitu tahan asam pada pewarnaan. Tujuan: Penelitian ini bertujuan untuk mengetahui gambaran asupan dan status gizi pasien rawat inap penyakit tuberkulosis di RSUD Labuang Baji Makassar tahun 2018. Metode: Penelitian ini mengambil data sebanyak 67 rekam medis pasien rawat inap penyakit tuberkulosis. Pendataan rekam medis dimulai dari pencatatan karakteristik pasien hingga asupan dan status gizinya. Data sekunder dianalisis menggunakan distribusi frekuensi. Hasil: Jumlah pasien tuberkulosis terbanyak terdapat pada kelompok usia dewasa akhir 33 pasien $(49,3 \%)$, jenis kelamin laki-laki 39 pasien $(58,2 \%)$, status pendidikan SD 21 pasien $(31,3 \%)$, status pekerjaan tidak bekerja 30 pasien $(44,8 \%)$, dan pasien keluar rumah sakit dengan keadaan membaik 67 pasien (100\%). Pada asupan energi dan zat gizi makro terbanyak pada asupan sedang (80\%-99\%) 41 pasien $(61,2 \%)$, pasien yang mengonsumsi suplemen terbanyak yaitu vitamin $\mathrm{C}$ dan vitamin $\mathrm{K} 6$ pasien (9\%). Konsistensi makanan yaitu konsistensi lunak 34 pasien $(50,7 \%)$, dan jalur pemberian makanan terbanyak yaitu peroral 67 pasien $(100 \%)$. Pada status gizi terbanyak yaitu pasien berstatus gizi kurang 36 pasien (53,7\%). Penyakit penyerta terbanyak yaitu DM Tipe II 12 pasien (17,9\%). Lama perawatan terbanyak pada durasi 7 hari 12 pasien $(17,9 \%)$ dan durasi terlama adalah 21 hari 1 pasien (1,5\%). Kesimpulan: Proporsi asupan terbanyak yaitu asupan sedang (80\%-99\%) 41 pasien (61,2\%), asupan kurang (70\%-80\%) 23 pasien (34,3\%). Status gizi pasien tuberkulosis terbanyak status gizi kurang 36 pasien $(53,7 \%)$.
\end{abstract}

\section{Kata kunci : Asupan, Status Gizi, Tuberculosis}

\section{ABSTRACT}

Introduction: Tuberculosis is an infectious disease caused by a systematic (overall) Mycobacterium. This Mycobacterium germ is rod-shaped, has special properties, namely acid resistance to staining. Purpose: This study aims to describe the nutritional intake and status of inpatients of tuberculosis in Labuang Baji Makassar Hospital in 2018. Methods: This study took 67 medical records of inpatients with tuberculosis. Data collection of medical records 
starts from recording patient characteristics to nutritional intake and status. Secondary data were analyzed using frequency distribution. Results: The highest number of tuberculosis patients was in the final adult age group of 33 patients (49.3\%), male sex 39 patients (58.2\%), elementary education status 21 patients (31.3\%), employment status was not worked 30 patients (44.8\%), and patients were discharged from the hospital with 67 patients (100\%). In the most energy intake and macro nutrients at moderate intake (80\% -99\%) 41 patients $(61.2 \%)$, patients taking the most supplements were vitamin $C$ and vitamin $K 6$ patients (9\%). Food consistency is soft consistency of 34 patients (50.7\%), and the highest feeding pathway is oral 67 patients (100\%). In the most nutritional status, the patients were malnourished with 36 patients (53.7\%). The most common comorbidities were Type II DM 12 patients (17.9\%). The highest duration of treatment was 7 days 12 patients (17.9\%) and the longest duration was 21 days 1 patient (1.5\%). Conclusion: The highest proportion of intake is moderate intake (80\% -99\%) 41 patients (61.2\%), less intake (70\% -80\%) 23 patients $(34.3 \% \neg)$. The nutritional status of the most tuberculosis patients was less nutritional status of 36 patients $(53.7 \%)$.

\section{Keywords: Intake, Nutritional Status, Tuberculosis}

\section{PENDAHULUAN}

Tuberkulosis merupakan penyakit infeksi akibat kuman Mycobacterium yang bersifat sistematis (menyeluruh) sehingga dapat mengenai hampir seluruh organ tubuh, dengan lokasi terbanyak di paru-paru yang biasanya merupakan lokasi infeksi yang pertama kali terjadi. Kuman Mycobacterium ini berbentuk batang, mempunyai sifat khusus yaitu tahan asam pada pewarnaan. Oleh karena itu disebut pula sebagai Basil Tahan Asam (BTA). ${ }^{2}$

Menurut WHO pada tahun 2014 orang yang terkena tuberkulosis sebanyak 9,6 juta. Secara global, India dan Indonesia memilki jumlah kasus tertinggi berturut-turut sebanyak $23 \%$ dan 10\% kasus global. Pada tahun 2014, Indonesia menduduki urutan kedua dengan prevalensi tertinggi di Asia Tenggara setelah Timor Leste. Prevalensi tuberkulosis di Indonesia pada tahun 2014 adalah 647 per 100.000 penduduk, sedangkan insidennya ditemukan sebanyak 399 kasus per 100.000 penduduk. ${ }^{1}$

Bila dikaitkan dengan status gizi bahwa gizi merupakan faktor pendukung bagi penanggulangan penyakit infeksi seperti tuberkulosis, maka gizi yang seimbang dapat membantu mempercepat proses penyembuhan penyakit tuberkulosis. Risiko komplikasi, termasuk kematian pada pasien tuberkulosis dipengaruhi oleh status gizi secara individual. Status gizi dan utilisasi/penggunaan zat gizi menjadi terganggu akibat adanya infeksi. Selain itu dengan adanya infeksi, kebutuhan zat gizi menjadi meningkat karena tubuh memerlukan energi untuk melawan penyakit. ${ }^{4}$

Prevalensi penderita tuberkulosis dengan status gizi rendah adalah sekitar $60 \%$. Penderita tuberkulosis dewasa dengan nutrisi buruk memiliki risiko kematian 2 kali lipat. Penelitian yang dilakukan oleh Novi Maulidar tahun 2010 di Kabupaten Pidie Provinsi Aceh menunjukkan $73,68 \%$ penderita tuberkulosis paru memiliki status gizi kurang. Penelitian lain yang dilakukan oleh Indah Mahfuzah tahun 2014 di Pontianak menunjukkan 67,8\% penderita tuberkulosis paru memiliki status gizi kurang. Penelitian yang dilakukan oleh Jonathan A.J. 
Wokas tahun 2014 di Manado juga menunjukkan sebagian besar penderita tuberkulosis paru memiliki status gizi kurang yaitu sebesar $45,5 \%{ }^{3}$

Keadaan status gizi dan penyakit infeksi merupakan pasangan yang terkait. Infeksi dapat menyebabkan kekurangan gizi ataupun sebaliknya kurang gizi juga dapat menghambat dan memperburuk dalam mengatasi penyakit infeksi karena kekurangan gizi dapat menghambat reaksi pembentukan kekebalan tubuh. ${ }^{4}$ Oleh karena itu, berdasarkan uraian di atas maka dilakukan penelitian ini untuk melihat gambaran asupan dan status gizi pada pasien rawat inap penyakit tuberkulosis di RSUD Labuang Baji Makassar tahun 2018.

\section{BAHAN DAN METODE}

Penelitian ini menggunakan studi observasional deskriptif yang dilaksanakan di ruang instalasi rekam medik RSUD Labuang Baji Makassar pada bulan Juni 2019. Populasi dalam penelitian ini adalah semua rekam medis pasien rawat inap penyakit tuberkulosis di RSUD Labuang Baji Makassar dari bulan Januari-Desember tahun 2018. Pemilihan sampel pada penelitian ini dilakukan dengan menggunakan teknik non probability sampling dengan menggunakan total sampling. Total sampling digunakan dalam penelitian ini dikarenakan jumlah sampel dengan jumlah populasi yang ada dimana harus memperhatikan kriteria inklusi berupa rekam medik pasien tuberkulosis non HIV-AIDS, rekam medis pasien tuberkulosis baru dan/atau readmisi (tahun 2018), dan pasien tuberkulosis dengan kategori minimum dewasa awal (20-40 tahun), serta kriteria eksklusi berupa pasien dengan NCP yang tidak lengkap dalam rekam medik.

\section{HASIL}

Berdasarkan tabel 4.1 bahwa kisaran umur pasien tuberkulosis yaitu dewasa akhir (4160 tahun) sebesar 49,3\%. Pendidikan pasien paling banyak adalah SD/Sederajat yakni 31,3\%, dengan status pekerjaan tidak bekerja/IRT (ibu rumah tangga) sebesar 44,8\%, dan status perkawinan paling banyak yaitu kawin sebesar $85,1 \%$. Jenis pembiayaaan yang paling banyak digunakan oleh pasien yaitu JKN (Jaminan Kesehatan Naisonal) dalam hal ini adalah BPJS (Badan Penyelenggara Jaminan Sosial Kesehatan) sebesar 89,6\% dengan keadaan keseluruhan pasien keluar rumah sakit membaik.

Asupan sampel penelitian yaitu pasien tuberkulosis yang menjalani rawat inap meliputi asupan zat gizi makro, suplementasi, konsistensi makanan, dan jalur pemberian makan. 
Nalurinita Diniari: Gambaran Asupan dan Status Gizi pada Pasien Rawat Inap Penyakit Tuberkulosis di Rumah Sakit Umum Daerah Labuang Baji Makassar Tahun 2018

Tabel 1. Distribusi Karakteristik Pasien Rawat Inap Penyakit Tuberkulosis di RSUD Labuang Baji Makassar Tahun 2018

\begin{tabular}{|c|c|c|}
\hline \multirow{2}{*}{ Karakteristik Pasien } & \multicolumn{2}{|c|}{ Jumlah } \\
\hline & f (n) & $(\%)$ \\
\hline \multicolumn{3}{|l|}{ Umur } \\
\hline Dewasa Awal & 19 & 28,4 \\
\hline Dewasa Akhir & 33 & 49,3 \\
\hline Lansia & 15 & 22,4 \\
\hline Total & 67 & 100 \\
\hline \multicolumn{3}{|l|}{ Jenis Kelamin } \\
\hline Laki-laki & 39 & 58,2 \\
\hline Perempuan & 28 & 41,8 \\
\hline Total & 67 & 100 \\
\hline \multicolumn{3}{|l|}{ Pendidikan } \\
\hline Tidak Sekolah & 7 & 10,4 \\
\hline $\mathrm{SD}$ & 21 & 31,3 \\
\hline SMP & 11 & 16,4 \\
\hline SMA & 19 & 28,4 \\
\hline Diploma/Sarjana & 9 & 13,4 \\
\hline Total & 67 & 100 \\
\hline \multicolumn{3}{|l|}{ Pekerjaan } \\
\hline Tidak Bekerja/IRT & 30 & 44,8 \\
\hline Pedagang & - & - \\
\hline Wiraswasta/Karyawan & 21 & 31,3 \\
\hline PNS/TNI/POLRI & 1 & 1,5 \\
\hline Lainnya & 15 & 22,4 \\
\hline Total & 67 & 100 \\
\hline \multicolumn{3}{|l|}{ Status Perkawinan } \\
\hline Kawin & 57 & 85,1 \\
\hline Belum kawin & 7 & 10,4 \\
\hline Duda & - & - \\
\hline Janda & 3 & 4,5 \\
\hline Total & 67 & 100 \\
\hline \multicolumn{3}{|l|}{ Pembiayaan } \\
\hline Umum & 7 & 10,4 \\
\hline JKN & 60 & 89,6 \\
\hline Lainnya & - & - \\
\hline Total & 67 & 100 \\
\hline \multicolumn{3}{|l|}{ Keadaan Keluar RS } \\
\hline Sembuh & - & - \\
\hline Membaik & 67 & 100 \\
\hline Dirujuk ke RS lain & - & - \\
\hline Meninggal & - & - \\
\hline Total & 67 & 100 \\
\hline
\end{tabular}

Sumber: Data Primer 2018. 
Berdasarkan tabel 2. didapatkan hasil bahwa dari total 67 pasien tuberkulosis asupan energi dan zat gizi makro paling banyak berada pada kategori sedang (80\%-99\%) sebanyak 41 $(61,2 \%)$ pasien.

Tabel 2. Distribusi Asupan Energi dan Zat Gizi Makro Pasien Tuberkulosis di RSUD Labuang Baji Makassar Tahun 2018

\begin{tabular}{ccc}
\hline Zat Gizi Makro & \multicolumn{2}{c}{ Jumlah } \\
\cline { 2 - 3 } & $\mathbf{f}(\mathbf{n})$ & $\mathbf{( \% )}$ \\
\hline Habis $(100 \%)$ & 3 & 4,5 \\
Sedang $(80 \%-99 \%)$ & 41 & 61,2 \\
Kurang (70\%-80\%) & 23 & 34,3 \\
\hline Total & $\mathbf{6 7}$ & $\mathbf{1 0 0}$
\end{tabular}

Sumber: Data Primer 2018.

Berdasarkan tabel 3. didapatkan hasil bahwa dari total 67 pasien tuberkulosis jenis suplementasi yang paling banyak diberikan yaitu Vitamin $\mathrm{C}$ dan Vitamin $\mathrm{K}$ sebanyak 6 $(13,4 \%)$ pasien.

Tabel 3. Distribusi Asupan Zat Gizi Mikro Pasien Tuberkulosis di RSUD Labuang Baji Makassar Tahun 2018

\begin{tabular}{ccc}
\hline \multirow{2}{*}{ Zat Gizi Mikro } & \multicolumn{2}{c}{ Jumlah } \\
\cline { 2 - 3 } & $\mathbf{f ~ ( \mathbf { n } )}$ & $\mathbf{( \% )}$ \\
\hline Tidak Ada & 56 & 83,6 \\
Vitamin C+Vitamin K & 6 & 9 \\
Ca Glukonas+ViT C+Vit K & 2 & 3 \\
Vitamin B 6 & 1 & 1,5 \\
KCL & 1 & 1,5 \\
Neurobion & 1 & 1,5 \\
\hline Total & $\mathbf{6 7}$ & $\mathbf{1 0 0}$
\end{tabular}

Sumber: Data Primer 2018.

Berdasarkan tabel 4 didapatkan hasil dari total 67 pasien tuberkulosis konsistensi makanan yang diberikan pada pasien paling banyak berada pada kategori lunak sebanyak 34 $(50,7 \%)$ orang. 
Tabel 4. Distribusi Konsistensi Makanan Pasien Tuberkulosis di RSUD Labuang Baji Makassar Tahun 2018

\begin{tabular}{ccc}
\hline \multirow{2}{*}{ Jenis Diet } & \multicolumn{2}{c}{ Jumlah } \\
\cline { 2 - 3 } & $\mathbf{f}(\mathbf{n})$ & $\mathbf{( \% )}$ \\
\hline Biasa & 33 & 49,3 \\
Lunak & 34 & 50,7 \\
Saring & - & - \\
Cair & - & - \\
\hline Total & $\mathbf{6 7}$ & $\mathbf{1 0 0}$ \\
\hline
\end{tabular}

Sumber: Data Primer 2018.

Berdasarkan tabel 5 didapatkan hasil bahwa keseluruhan dari total 67 pasien tuberkulosis jalur pemberian makanan pasien yaitu melalui pemberian oral.

Tabel 5. Distribusi Asupan Jalur Pemberian Makan Pasien Tuberkulosis di RSUD Labuang Baji Makassar Tahun 2018

\begin{tabular}{lccc}
\hline \multirow{2}{*}{ Jalur Pemberian Makanan } & \multicolumn{2}{c}{ Jumlah } \\
\cline { 2 - 4 } & & $\mathbf{f}(\mathbf{n})$ & $\mathbf{( \% )}$ \\
\hline Oral & 67 & 100 \\
Enteral & - & - \\
Parenteral & Total & - & - \\
Kombinasi & - & - \\
\hline & & $\mathbf{6 7}$ & $\mathbf{1 0 0}$
\end{tabular}

Sumber: Data Primer 2018.

Berdasarkan tabel 6 didapatkan hasil bahwa dari total 67 pasien tuberkulosis yang memiliki status gizi sangat kurang sebanyak 36 (53,7\%) pasien, kurus sebanyak $9(13,4 \%)$ pasien, normal sebanyak $20(29,9 \%)$ pasien, dan yang memiliki status gizi obesitas sebanyak $2(3 \%)$ pasien.

Tabel 6. Distribusi Indeks Massa Tubuh Pasien Tuberkulosis di RSUD Labuang Baji Makassar Tahun 2018

\begin{tabular}{lccc}
\hline & \multirow{2}{*}{ Status Gizi } & \multicolumn{2}{c}{ Jumlah } \\
\cline { 3 - 4 } & & $\mathbf{f}(\mathbf{n})$ & $\mathbf{( \% )}$ \\
\hline Sangat Kurus & 36 & 53,7 \\
Kurus & 9 & 13,4 \\
Normal & 20 & 29,9 \\
Gemuk & - & - \\
Obesitas & Total & 2 & 3 \\
\hline & & $\mathbf{6 7}$ & $\mathbf{1 0 0}$
\end{tabular}

Sumber: Data Primer 2018. 
Tabel 7. Distribusi Pasien Tuberkulosis yang Memiliki Penyakit Penyerta di RSUD Labuang Baji Makassar Tahun 2018

\begin{tabular}{lcc}
\hline \multicolumn{1}{c}{ Penyakit Penyerta } & \multicolumn{2}{c}{ Jumlah } \\
\cline { 2 - 4 } Tidak Ada & f(n) & $(\%)$ \\
Kolik abdomen+Asma akut & 35 & 52,2 \\
Disepsia & 1 & 1,5 \\
Hiponatremia+DM Tipe II & 1 & 1,5 \\
DM Tipe II & 1 & 1,5 \\
Anemia & 12 & 17,9 \\
Hiperglikemia & 2 & 3 \\
DM Tipe II+Anemia & 1 & 1,5 \\
Kolik abdomen+Hipoalbuminemia & 1 & 1,5 \\
Gastritis Pain & 1 & 1,5 \\
Infeksi saluran kemih+Cholecystitis+Fraktur Thorax+Anemia & 1 & 1,5 \\
Gangguan Enzin Transminase & 1 & 1,5 \\
G. Enzim Transminase+Hipokalemia+Severe Energy Protein Malnutrition & 1 & 1,5 \\
Hydropneumothorax & 1 & 1,5 \\
Pneumonia & 1 & 1,5 \\
Pneumonia+Abses Paru & 1 & 1,5 \\
Hiponatremia+Hipokalemia & 1 & 1,5 \\
Hiponatremia+Hipoalbuminemia+Anemia & 1 & 1,5 \\
Hiponatremia & 1 & 1,5 \\
\hline & 2 & 3 \\
\hline
\end{tabular}

Sumber : Data Sekunder, 2018.

Tabel 8. Distribusi Lenght of Stay (LOS) Pasien Tuberkulosis di RSUD Labuang Baji Makassar Tahun 2018

\begin{tabular}{ccc}
\hline \multirow{2}{*}{$\begin{array}{c}\text { Lama Rawat Inap } \\
\text { (Hari) }\end{array}$} & f (n) & Jumlah \\
\cline { 2 - 3 } & 2 & $(\%)$ \\
\hline 3 & 5 & 3,0 \\
4 & 4 & 7,5 \\
5 & 8 & 6,0 \\
6 & 12 & 11,9 \\
7 & 10 & 17,9 \\
8 & 9 & 14,9 \\
9 & 3 & 13,4 \\
10 & 5 & 4,5 \\
11 & 3 & 7,5 \\
12 & 1 & 4,5 \\
13 & 2 & 1,5 \\
14 & 1 & 3,0 \\
19 & 1 & 1,5 \\
20 & 1 & 1,5 \\
21 & $\mathbf{6 7}$ & 1,5 \\
\hline Total & & $\mathbf{1 0 0}$ \\
\hline
\end{tabular}

Sumber: Data Sekunder, 2018.

Berdasarkan tabel 7 diperoleh hasil bahwa dari total 67 pasien tuberkulosis yang memiliki penyakit penyerta yang paling banyak dialami oleh pasien tuberkulosis adalah DM 
tipe II sebanyak $12(17,9 \%)$ pasien, anemia sebanyak 2 (3\%) pasien, dan hiponatremia sebanyak $2(3 \%)$ pasien. Selanjutnya pada tabel 8 didapatkan hasil bahwa Lenght of Stay (LOS) pasien tuberkulosis dari total 67 pasien paling banyak yaitu 7 hari sebesar 17,9\% .

\section{PEMBAHASAN}

Berdasarkan karakteristik pasien tuberkulosis yang menjalani rawat inap di RSUD Labuang Baji Makassar pada tahun 2018 tiap kategori karateristik memiliki perbedaan masing-masing. Pada kategori Usia pasien tuberkulosis yang menjalani rawat inap di RSUD Labuang Baji Makassar dalam penelitian ini paling banyak berada pada usia dewasa akhir (41-60 tahun). Hal ini sesuai dengan prevalensi tuberkulosis Kemenkes RI tahun 2013-2014 yang menyatakan bahwa usia 45 tahun keatas memiliki prevalensi tertinggi terjangkitnya penyakit tuberkulosis dibandingkan kelompok lainnya, karena semakin bertambahnya usia semakin tinggi kemungkinan terjadinya reaktivitas tuberkulosis dan durasi paparan tuberkulosis lebih lama dibandingkan kelompok umur dibawahnya. ${ }^{5}$

Berdasarkan penelitian ini jenis kelamin pasien tuberkulosis yang menjalani rawat inap di RSUD Labuang Baji Makassar lebih banyak laki-laki yaitu berjumlah 39 (58,2\%) pasien, dibandingkan perempuan yaitu berjumlah $28(41,8 \%)$ pasien. Hasil penelitian ini sesuai dengan penelitian Indah Mahfuzhah tahun 2014 mengenai gambaran faktor risiko penderita tuberkulosis paru berdasarkan status gizi dan pendidikan di Poli Paru RSUD dr. Soedarso Pontianak didapatkan 159 (64,1\%) penderita tuberkulosis adalah laki-laki. Hal ini disebabkan karena laki-laki memiliki mobilitas yang tinggi dari pada perempuan sehingga kemungkinan terpajanan oleh kuman tuberkulosis lebih tinggi. Selain itu gaya hidup seperti merokok, mengkonsumsi minuman beralkohol dan risiko pekerjaan yang berasal dari polutan udara dari luar ruangan khususnya yang berhubungan dengan paparan industri juga dapat meningkatkan risiko terinfeksi tuberkulosis. ${ }^{3}$

Berdasarkan penelitian ini status pendidikan pasien tuberkulosis yang menjalani rawat inap di RSUD Labuang baji Makassar tahun 2018 paling banyak pada pendidikan sekolah dasar yaitu $21(31,3 \%)$ orang. Penelitian ini sesuai dengan penelitian yang dilakukan oleh Oktavia S, dkk tahun 2016 mengenai analisis faktor resiko kejadian tuberkulosis paru di wilayah kerja Puskesmas Kertapati Palembang didapatkan bahwa rata-rata pasien tuberkulosis memiliki pendidikan yang rendah yaitu pendidikan sekolah dasar sebesar 60,6\%. Hal ini disebabkan karena pendidikan dapat mempengaruhi pengetahuan seseorang diantaranya pengetahuan mengenai penyakit tuberkulosis, pencegahan dan pengobatannya, serta tempat tinggal yang memenuhi syarat kesehatan sehingga dengan pengetahuan yang cukup maka seseorang akan mencoba berperilaku bersih dan sehat. Semakin tinggi pendidikan seseorang, maka semakin rendah akan terjadinya penyakit tuberkulosis. ${ }^{6}$

Berdasarkan hasil penelitian ini status pekerjaan pasien tuberkulosis yang menjalani rawat inap di RSUD Labuang Baji Makassar tahun 2018 dari 67 pasien didapatkan 30 $(44,8 \%)$ orang tidak bekerja. Pasien tuberkulosis yang tidak bekerja terdiri dari pasien yang memang tidak mempunyai pekerjaan, pensiunan, ibu rumah tangga dan pelajar. Hasil penelitian ini sesuai dengan penelitian yang dilakukan oleh Erfina Mallinda tentang profil penderita tuberkulosis paru yang di rawat inap di bagian paru Rumah Sakit Umum Daerah Provinsi Riau periode 1 Januari-31 Desember 2013 didapatkan hasil pasien yang tidak bekerja yaitu berjumlah 30 (60\%) orang. Jenis pekerjaan mempunyai kaitannya dengan sosial 
ekonomi karena terdapat hubungan antara penghasilan yang didapat. Seseorang dengan ekonomi yang rendah maka cenderung sulit untuk mendapatkan pengobatan dan asupan gizi yang kurang. ${ }^{3}$

Berdasarkan penelitian ini dari total 67 pasien tuberkulosis yang menjalani rawat inap di RSUD Labuang baji Makassar pada tahun 2018 rata-rata asupan energi dan zat gizi makro berada pada kategori sedang (80\%-90\%) yaitu sebesar 61,2\%. Penelitian ini tidak sejalan dengan penelitian yang dilakukan oleh Puspita, dkk 2016 mengenai gambaran status gizi pada pasien tuberkulosis paru (TB Paru) yang menjalani rawat jalan di RSUD Arifin Achmad Pekanbaru didapatkan hasil bahwa resiko malnutrisi sebanyak 43 orang (60,7\%). Infeksi tuberkulosis dapat menyebabkan peningkatan kebutuhan energi serta perubahan metabolisme yang dapat memperburuk status nutrisi sehingga akhirnya terjadi malnutrisi. Sebaliknya malnutrisi dapat mempengaruhi manifestasi klinis dari tuberkulosis sebagai akibat dari kelemahan sistem imun. $^{7}$

Berdasarkan penelitian ini didapatkan hasil bahwa mikronutrien yang paling banyak diberikan pada pasien tuberkulosis yang menjalani rawat inap di RSUD Labuang Baji Makassar tahun 2018 yaitu vitamin C dan vitamin K sebanyak 6 (9\%) orang. Vitamin C berperan sebagai antioksidan sangatlah penting untuk pasien tuberkulosis, dimana Vitamin $\mathrm{C}$ bekerja pada jaringan ikat fibroblastic yang berfungsi sebagai eksudatif. Berdasarkan hasil penelitian Nugroho, dkk 2013 menunjukkan dengan pemberian Vitamin C 500 mg/hari selama 5-10 hari mampu meningkatkan berat badan, pengurangan pada lesi tuberkulosis serta mampu menurunkan frekuensi batuk dan dahak secara signifikan. ${ }^{8}$

Berdasarkan penelitian ini konsistensi makanan pasien tuberkulosis yang menjalani rawat inap di RSUD Labuang Baji Makassar tahun 2018 didapatkan hasil bahwa total dari 67 pasien tuberkulosis konsistensi makanan yang diberikan paling banyak pada kategori lunak sebanyak 34 (50,7\%) orang. Konsistensi pemberian makanan pasien yang lunak dikarenakan kondisi pasien yang sering mengalami sesak napas. Makanan diberikan dalam porsi kecil dengan frekuensi sering lebih dianjurkan dari pada makan dengan porsi besar tiga kali sehari. ${ }^{9}$

Berdasarkan penelitian ini jalur pemberian makanan pada pasien tuberkulosis yang menjalani rawat inap di RSUD Labuang Baji Makassar tahun 2018 didapatkan hasil bahwa dari total 67 pasien jalur pemberian makanan melalui oral atau mulut dikarenakan pasien masih bisa menelan cukup makanan. Apabila kondisi pasien tidak memungkingkan untuk diberikan makanan melalui oral maka akan dilanjutkan pemberian makanan secara enteral atau melalui jalur pipa, pasien dengan keadaan khusus akan diberikan makanan melalui parenteral atau jalur intra vena sentral/periver. ${ }^{9}$

Berdasarkan penelitian ini mengenai status gizi pasien tuberkulosis yang menjalani rawat inap di RSUD Labuang Baji Makassar tahun 2018 didapatkan hasil bahwa pasien yang memiliki status gizi sangat kurus sebanyak 36 (53,7\%) orang. Hasil penelitian ini sesuai dengan penelitian yang dilakukan oleh Arsunan Arsin dkk. Pada tahun 2012 terhadap penderita tuberkulosis paru BTA positif yang berobat di Pelayanan Kesehatan BBKPM Makassar didapatkan sebanyak 51,3\% penderita tuberculosis paru memiliki status gizi kurang. Hal ini terjadi karena salah satu faktor yang mempengaruhi terjangkitnya penyakit tuberkulosis adalah status gizi. Terdapat hubungan timbal balik antara status gizi kurang dan risiko terjangkit penyakit tuberkulosis. Status gizi yang buruk akan meningkatkan risiko 
terhadap penyakit tuberkulosis. Sebaliknya, penyakit tuberkulosis dapat mempengaruhi status gizi penderita karena proses perjalanan penyakitnya. ${ }^{3}$

Berdasarkan penelitian ini dari total 67 pasien tuberkulosis yang dirawat inap di RSUD Labuang Baji Makassar tahun 2018 memiliki 18 penyakit penyerta 3 tertinggi diantaranya adalah DM Tipe II sebanyak 12 (17,9\%) pasien, Anemia sebanyak 2 (3\%) pasien, dan Hiponatremia sebanyak $2(3 \%)$ pasien. Diabetes mellitus merupakan penyakit kronik berkaitan dengan gangguan fungsi imunitas tubuh, sehingga penderita rentan terhadap infeksi, termasuk tuberkulosis paru. Penyebab infeksi tuberkulosis pada penderita diabetes mellitus kebanyakan akibat adanya gangguan fungsi sel-sel imun dan mekanisme pertahanan tubuh, termasuk gangguan fungsi dari epitel pernapasan serta motilitas silia. ${ }^{10}$

Berdasarkan penelitian ini lama rawat inap pasien tuberkulosis di RSUD Labuang Baji Makassar tahun 2018, nilai rata-rata rawat inap pasien yaitu $17,9 \%, 11,9 \%$, dan $13,4 \%$ pada hari ke 7,8 dan 9 . Pasien tuberkulosis yang di rawat inap umumnya tidak memerlukan waktu yang lama apabila kondisi pasien sudah merasa membaik, maka pasien akan diizinkan pulang. Penelitian ini sesuai dengan penelitian yang dilakukan oleh Iskandar, dkk tahun 2012 mengenai evaluasi penggunaan obat tuberkulosis pada pasien rawat inap di ruang perawatan kelas III di salah satu rumah sakit di Bandung didapatkan hasil lama rawat inap pasien ratarata 1 sampai 2 minggu yaitu 38,37\% dan 39,54\%. Lama rawat pada pasien tuberkulosis tergantung pada keparahan kondisi pasien serta penyakit penyerta yang dialami pasien. ${ }^{11}$

\section{KESIMPULAN}

Berdasarkan hasil penelitian ini, maka dapat disimpulkan bahwa gambaran asupan dan status gizi pasien rawat inap penyakit tuberkulosis RSUD Labuang Baji Makassar yaitu asupan pasien tuberkulosis sangat kurang hal ini disebabkan asupan makanan yang tidak adekuat, dan penyakit infeksi tuberkulosis yang dialami pasien sehingga mempengaruhi status gizi pasien yang dilihat dari IMT pasien.

\section{DAFTAR PUSTAKA}

1. Murwaningrum A, Abdullah M, Makmun D. Pendekatan Diagnosis dan Tatalaksana Tuberkulosis Intestinal. 2016;3(2):165-73.

2. Kemenkes. Pedoman Pelayanan Gizi Rumah Sakit. 2013.

3. Putri WA, Munir SM, Chiristianto E. Gambaran Status Gizi Pada Pasien Tuberkulosis Paru (TB Paru) Yang Menjalani Rawat Inap Di RSUD Arifin Achmad Pekan Baru. 2016;3(2):1-16.

4. Yuniar I, Sarwono, Lestari SD. Hubungan Status Gizi dan Pendapatan Terhadap Kejadian Tuberkulosis Paru. 2017;1(1):14-22.

5. Kemenkes RI. Pusat Data dan Informasi Tuberkulosis. InfoDATIN [Internet]. 2018;

6. Oktavia S, Mutahar R, Destriatania S. Analisis Faktor Risiko Kejadian TB Paru di Wilayah Kerja Puskesmas Kertapati Palembang. J Ilmu Kesehat Masy. 2016;7(2):124-38.

7. Puspita E, Christianto E, Yovi I. Gambaran Status Gizi Pada Pasien Tuberkulosisi Paru (TB Paru) Yang Menjalani Rawat Jalan Di RSUD Arifin Achmad Pekan Baru. 2016;3(2). 
8. Nugroho EJ, Sulastri B, Maliya A. Pengaruh Pemberian Vitamin C Terhadap Nilai Limfosit pada Pasien Tubercolose di Wilayah Kerja Puskesmas Kradenan Kabupaten Grobogan. 2013.

9. Rahardja FM. Nutrisi Pada Tuberkulosis Paru dengan Malnutrisi. DAMIANUS J Med [Internet]. 2015;14(1):80-8.

10. Khitami Aziz K. Pengobatan Tuberkulosis Paru dan Diabetes Melitus serta Pengaruhnya terhadap Risiko Multi-Drug Resistant Tuberculosis (MDR-TB). Anat Med J Fak Kedokt [Internet]. 2019;2(1):22-32. Available from: http://jurnal.umsu.ac.id/index.php/AMJ

11. Elin Yulinah Sukandar, Sri Hartina H. Evaluasi Penggunaan Obat Tuberkulosis pada Pasien Rawat Inap di Ruang Perawatan Kelas III di Salah Satu Rumah Sakit di Bandung. Acta Pharm Indones. 2017;37(4):153-8. 